\title{
Forensic Science Curricular and Career Planning: A Modified System Theory- Based Model for Student Advising
}

\author{
Albert $\mathrm{AM}^{* 1}$, Schwartz JE${ }^{1}$ and Arnold $\mathrm{AN}^{2}$ \\ ${ }^{1}$ Department of Anthropology, University of North Carolina, North Carolina, United States \\ ${ }^{2}$ Department of Biology University of North Carolina, North Carolina, United States
}

${ }^{*}$ Corresponding author: Albert AM, Department of Anthropology, University of North Carolina, 601 S. College Road, Wilmington, NC 28403, United States, E-mail: albertm@uncw.edu

Citation: Albert AM, Schwartz JE, Arnold AN (2017) Forensic Science Curricular and Career Planning: A Modified System Theory-Based Model for Student Advising. J Forensic Sci Criminol 5(4): 403

Received Date: August 18, 2017 Accepted Date: September 11, 2017 Published Date: September 13, 2017

\begin{abstract}
Following the rise in popularity of forensic science, fueled by the media and perhaps necessity, comes the demand for an effective and productive approach to advising students interested in a career in this vast area. Forensic science is a large-scale umbrella term encompassing a multitude of disciplines. Whereas "forensic" means legal, any discipline that has an application to law or the legal system may be considered a "forensic science". With the seemingly ever-increasing lure of forensic science as a career option, the question arises as to how best to assist students in making a dream job a reality. The purpose of this research is twofold: (1) summarize findings from forensic science job listings in the United States and (2) provide a framework, derived largely from Systems Theory, for understanding the advisee skillset, and suggest a model for a step by step career decision-making and curricular planning approach for professionals working in an advising capacity.
\end{abstract}

Keywords: Forensic science careers; Forensic science jobs; Forensic science employment; Forensic science education; Forensic science advising

\section{Introduction}

\section{Popularity of forensic science and dispelling myths}

Following the rise in popularity of forensic science, fueled by the media and perhaps necessity, comes the demand for an effective and productive approach to advising students interested in a career in this vast area [1,2]. Forensic science is a large-scale umbrella term encompassing a multitude of disciplines. Whereas "Forensic" means legal, any discipline that has an application to law or the legal system may be considered a "Forensic Science".

For students interested in a career in forensic science, they may present to the advisor a somewhat unrealistic idea of what job they are seeking, and therefore what courses they should take to get that job. For example, a student may claim to want to be a forensic scientist (a general term), but say he or she is not a "science" person or a "math" person. Not surprisingly, many of the so-called forensic science jobs are those involving evidence analysis, such as DNA, fingerprinting, blood spatter (i.e., biology), toxicology (i.e., chemistry), ballistics, and crime scene reconstruction (i.e., physics), among others. This discrepancy in career affinity and educational requirements is likely rooted in what has come to be known as the "CSI Effect" [3-5].

The "CSI Effect" emerged out of television programs glamorizing crime scene investigators (CSIs) and the capabilities of forensic analysts. The main point is that viewers of these television programs come to believe that what they see on TV can be directly translated to the courtroom. On TV, DNA is processed in a day or two whereas in real life it could take months or years; toxicology results are achieved within hours but in real life it could be days or weeks. Further, there is an expectation among jurors in a courtroom that all forensic analyses should be high-tech, fast, and completely accurate [3-5].

The CSI Effect in a sense has bled out to affect viewers of forensic TV programs in terms of their ideas about what is involved in the education and training, and preparation and experience gained on the road to becoming a certain type of forensic science practitioner. To be sure, there are widely disparate undergraduate majors that can prepare students for myriad forensic science jobs, ranging from the technical, to methodological, to theoretical. Moreover, some forensic science jobs accept the high school diploma as a minimum, with work experience, while others suggest a bachelor's or master's degree, with yet more specialized areas requiring 
a doctorate, medical, or jurisprudence degree. Thus, students avidly carving out a career path in forensic science require advising that (1) dispels the myths emanating from the CSI Effect, (2) determines the best area of focus, such as biology, chemistry, physics or a social science, such as criminology, psychology, or anthropology, and (3) provides a clear-cut method to target a specific job goal to start their career development.

\section{Rationale}

During a previous semester, we-one professor (and forensic science minor coordinator) and two undergraduate students (one biology major and one dual major in biology and anthropology) — collaborated on a research project aimed at data-mining the Internet for current forensic science job listings, collecting information on job titles, descriptions of duties, qualifications, required education and experience and so forth. The students compiled tables comparing results of similarities and differences in the various jobs posted. From there, we worked together to devise a step by step process to identify areas of student competence to match a desired job, which we share here for other advisors.

The impetus for disseminating this information derives from anecdotal feedback from students. Despite the best efforts of academic advisors and career counselors, many students often come away unclear about their curricular route or how to figure out what they want to do, much less where to look for the actual jobs for which to apply. Further, even if students have clarity on the courses needed to graduate with a specific major, this does not necessarily qualify students for a job in their desired forensic science area. Many jobs in forensic science require myriad courses in various disciplines. Good advising will ensure students not only meet major requirements for graduation, but also meet job-hiring expectations.

With the seemingly ever-increasing lure of forensic science as a career option, the question arises as to how best to assist students in making a dream job a reality. The purpose of this research is twofold: (1) summarize findings from forensic science job listings and (2) provide a framework, derived largely from Systems Theory, for understanding the advisee skillset, and suggest a model for a step by step career decision-making and curricular planning approach for professionals working in an advising capacity.

What follows in the Methods and Results sections is how forensic science jobs were identified and what their key components were. And, in the Discussion section, through a modified Systems Theory-based process, we suggest techniques to aid in evaluating the most suitable jobs available to advisees based on their interests and competencies, how to find those jobs, and how to analyze qualifications needed and plan a curriculum accordingly.

\section{Materials and Methods}

\section{Approach}

The approach to gathering information on skills and qualifications, and oftentimes experience, needed for various employment opportunities in forensic science involved locating current job listings first, before curricular planning. From the details posted in job listings, advisors gain insights into what their advisees need to fulfill their education and training at the undergraduate level in preparation for job readiness. By working with a concrete end goal (i.e., an actual job listing), the ambiguity of course planning is lessened; and students can formulate a clear path toward accomplishing appropriate coursework, internships, research experience, and so forth well in advance. Expectations for what to know are elucidated and students can feel more confident and become more efficient in working toward their degree.

To demonstrate how the above approach works, the authors conducted a detailed data mining research project whereby job listings posted during a specific four-week period (mid-September to mid-October 2016) were collected and analyzed [6,7]. Findings from the job listings were classified and key skillsets, coursework, experience and qualifications were noted. These items were then organized for use in advising students on realistic job prospects to enable curricular planning.

\section{Data collection}

Data for this study were job listings derived from two major highly esteemed sources in the field of forensic science: (1) the website of the American Academy of Forensic Sciences, www.aafs.org, a professional organization for forensic science practitioners, and (2) the website www.Crime-Scene-Investigator.net [6,7]. It is noteworthy that the forensic job searches on the two websites were geared toward employment that excludes extensive post-graduate training. Specifically, jobs requiring a doctorate (PhD), medical/ dental degree (MD, DMD, DDS), or law degree (JD) were beyond the scope of this research. The intended focus group was undergraduate college students seeking a four-year degree, Bachelor of Arts (BA) or Bachelor of Science (BS), in a social science (e.g., criminology, anthropology, psychology) or "hard" science (e.g., biology, chemistry) major area, respectively. Also, excluded from the job listings search were advanced positions; the aim was to identify entry-level job openings where possible. From over 100 hundred job listings, nearly half $(n=49)$ were deemed entry-level and geared toward our focus group.

\section{Data analysis}

Once a job listing was identified as applicable in that it met the criteria of being entry-level or slightly above, requiring no more than a four-year degree, and lacking extensive prior experience, it was dissected into several components and entered in a Microsoft Excel 
spreadsheet. The components of the spreadsheet were: job type, degree/required coursework, elective coursework, experience, additional requirements, and salary (in US dollars). Gross observations of the data analyzed in the spreadsheet yielded information useful for education and career advising sessions, and is reported and discussed in the following sections.

\section{Results}

From a sample size of over 100 job listings, 49 were deemed relevant based on the above-mentioned criteria. The 49 positions were distributed across 11 different job titles. An evaluation of these job titles, and the position description and requirements, resulted in classifying the jobs according to three major clusters (see Table 1,2 and 3).

\begin{tabular}{|c|c|c|c|c|c|c|}
\hline Job title & $\mathbf{N}$ & $\begin{array}{l}\text { Degree/required } \\
\text { coursework }\end{array}$ & $\begin{array}{c}\text { Elective } \\
\text { coursework }\end{array}$ & Experience & $\begin{array}{l}\text { Additional } \\
\text { requirements }\end{array}$ & $\begin{array}{c}\text { Salary in US } \\
\text { dollars (\$) }\end{array}$ \\
\hline Criminalist & 7 & $\begin{array}{l}\text { BS in biology, } \\
\text { chemistry, forensic } \\
\text { science, physics, } \\
\text { entomology, } \\
\text { biochemistry or } \\
\text { any closely related } \\
\text { field }\end{array}$ & $\begin{array}{l}\text { Genetics, } \\
\text { molecular biology, } \\
\text { ecology, chemistry, } \\
\text { biology, statistics }\end{array}$ & $\begin{array}{c}\text { 1+ years full time } \\
\text { criminalistics or } \\
\text { forensic science } \\
\text { experience } \\
\text { Some require } 4+ \\
\text { years if the } 1 \text { year } \\
\text { was not at least } \\
\text { an entry level } \\
\text { criminalist }\end{array}$ & $\begin{array}{l}\text { Provide DNA } \\
\text { sample, basic } \\
\text { computer skills, } \\
\text { organized, conflict } \\
\text { resolution skills }\end{array}$ & $\begin{array}{c}\text { Mean }=59,656 \\
\operatorname{Min}=49,796 \\
\text { Max }=98,075 \\
\text { Mode }=50,000 \mathrm{~s}\end{array}$ \\
\hline $\begin{array}{l}\text { Crime scene } \\
\text { investigator }\end{array}$ & 5 & $\begin{array}{l}1 \text { requires a high } \\
\text { school diploma/ } \\
\text { GED } \\
1 \text { requires at least } \\
\text { an AS degree } \\
3 \text { require a BS in a } \\
\text { science, criminal } \\
\text { justice, etc. }\end{array}$ & None specified & $\begin{array}{l}\text { Certification as a } \\
\text { CSI preferred } \\
1+\text { years' } \\
\text { experience if not } \\
\text { entry level }\end{array}$ & $\begin{array}{l}\text { Clean criminal } \\
\text { history, basic } \\
\text { computer skills, no } \\
\text { drug use in the past } \\
2 \text { years }\end{array}$ & $\begin{array}{c}\text { Mean }=35,754 \\
\text { Min }=33,924 \\
\text { Max }=37,585 \\
\text { Mode }=30,000 \text { s }\end{array}$ \\
\hline
\end{tabular}

$\mathrm{N}$ total $=12$

Table 1: Crime scene investigator and evidence collection jobs

\begin{tabular}{|c|c|c|c|c|c|c|}
\hline Job title & $\mathbf{N}$ & $\begin{array}{l}\text { Degree/ required } \\
\text { coursework }\end{array}$ & $\begin{array}{c}\text { Elective } \\
\text { coursework }\end{array}$ & Experience & $\begin{array}{c}\text { Additional } \\
\text { requirements }\end{array}$ & $\begin{array}{c}\text { Salary in US } \\
\text { dollars (\$) }\end{array}$ \\
\hline $\begin{array}{l}\text { Breath } \\
\text { alcohol }\end{array}$ & 2 & $\begin{array}{l}\text { BS in chemistry, } \\
\text { biology, forensic } \\
\text { science; } \\
\text { MS or PhD } \\
\text { preferred in } \\
\text { toxicology or } \\
\text { related field }\end{array}$ & $\begin{array}{l}\text { Toxicology, } \\
\text { pharmacology, } \\
\text { statistics }\end{array}$ & $\begin{array}{c}1 \text { preferred } \\
\text { completion of } \\
\text { Intex EC/IR II } \\
\text { maintenance } \\
\text { course and Robert } \\
\text { F Berkenstein } \\
\text { alcohol course }\end{array}$ & $\begin{array}{l}\text { Valid driver's } \\
\text { license, } \\
\text { communicate } \\
\text { effectively verbally } \\
\text { and in writing, } \\
\text { background check, } \\
\text { analytical skills, } \\
\text { expert witness } \\
\text { testimony }\end{array}$ & $\begin{array}{l}\text { Trainee }=44,472 \\
(51,142-85,558)\end{array}$ \\
\hline $\begin{array}{l}\text { Questioned } \\
\text { documents }\end{array}$ & 1 & BS degree & None specified & $\begin{array}{c}2 \text { years full } \\
\text { time training } \\
\text { in question doc } \\
\text { examination } \\
\text { preferred }\end{array}$ & $\begin{array}{l}\text { Background check, } \\
\text { drug test, provide } \\
\text { DNA sample }\end{array}$ & No salary posted \\
\hline $\begin{array}{l}\text { Latent } \\
\text { prints }\end{array}$ & 2 & $\mathrm{BA}$ or BS degree & $\begin{array}{c}\text { Science coursework } \\
\text { preferred }\end{array}$ & $\begin{array}{l}3 \text { years as a latent } \\
\text { print examiner }\end{array}$ & $\begin{array}{l}\text { Detail oriented, } \\
\text { communicate } \\
\text { effectively verbally } \\
\text { and in writing, } \\
\text { valid driver's } \\
\text { license, heavy } \\
\text { lifting, organized }\end{array}$ & No salary posted \\
\hline $\begin{array}{c}\text { Digital } \\
\text { evidence }\end{array}$ & 1 & $\begin{array}{l}\text { BS in computer } \\
\text { science or } \\
\text { computer } \\
\text { engineering }\end{array}$ & None specified & $\begin{array}{l}\text { At least } 1 \text { year } \\
\text { in a forensic or } \\
\text { law enforcement } \\
\text { setting }\end{array}$ & $\begin{array}{c}\text { Knowledge of } \\
\text { computers, digital } \\
\text { photography, GPS, } \\
\text { ATM, etc. }\end{array}$ & No salary posted \\
\hline $\begin{array}{l}\text { Evidence } \\
\text { handling }\end{array}$ & 1 & $\begin{array}{l}\text { BS in a field of } \\
\text { science }\end{array}$ & None specified & $\begin{array}{c}\text { At least } 1 \text { year } \\
\text { in a forensic or } \\
\text { law enforcement } \\
\text { setting }\end{array}$ & $\begin{array}{l}\text { Communicate } \\
\text { effectively verbally } \\
\text { and in writing, } \\
\text { analytical and } \\
\text { problem solving } \\
\text { skills, knowledge of } \\
\text { Microsoft office }\end{array}$ & No salary posted \\
\hline
\end{tabular}

$\mathrm{N}$ total $=7$

Table 2: Evidence specific jobs 


\begin{tabular}{|c|c|c|c|c|c|c|}
\hline Job title & $\mathbf{N}$ & $\begin{array}{c}\text { Degree/required } \\
\text { coursework }\end{array}$ & $\begin{array}{c}\text { Elective } \\
\text { coursework }\end{array}$ & Experience & $\begin{array}{c}\text { Additional } \\
\text { requirements }\end{array}$ & $\begin{array}{l}\text { Salary in US } \\
\text { dollars (\$) }\end{array}$ \\
\hline $\begin{array}{l}\text { Forensic } \\
\text { scientist I }\end{array}$ & 7 & $\begin{array}{l}\text { Minimum BS in } \\
\text { biology, chemistry, } \\
\text { forensic science or } \\
\text { related field }\end{array}$ & $\begin{array}{l}\text { Biochemistry, } \\
\text { genetics, molecular } \\
\text { biology, statistics }\end{array}$ & $\begin{array}{l}\text { Some experience in } \\
\text { a lab preferred but } \\
\text { not required for } \\
\text { entry level position }\end{array}$ & $\begin{array}{l}\text { Background } \\
\text { check, good vision } \\
\text { and hearing, } \\
\text { communicate } \\
\text { effectively verbally } \\
\text { and in writing }\end{array}$ & $\begin{array}{c}\text { Mean }=57,043 \\
\operatorname{Min}=44,472 \\
\text { Max }=92,525 \\
\text { Mode }=40,000 \mathrm{~s}\end{array}$ \\
\hline $\begin{array}{l}\text { Forensic } \\
\text { scientist II } \\
\text { and up }\end{array}$ & 9 & $\begin{array}{l}\text { Minimum BS in } \\
\text { biology, chemistry, } \\
\text { natural science, } \\
\text { criminal justice, or } \\
\text { related field } \\
\text { Some upper level } \\
\text { jobs require a MS } \\
\text { or PhD }\end{array}$ & $\begin{array}{c}\text { Statistics/ } \\
\text { population } \\
\text { genetics, } \\
\text { biochemistry, } \\
\text { genetics, molecular } \\
\text { biology, organic } \\
\text { chemistry }\end{array}$ & $\begin{array}{c}\text { Majority require } 3+ \\
\text { years in a forensic } \\
\text { laboratory setting } \\
\text { If you have an } \\
\text { advanced degree, } \\
1+\text { years is } \\
\text { normally required }\end{array}$ & $\begin{array}{l}\text { Background check, } \\
\text { good hearing } \\
\text { and vison, drug } \\
\text { test, valid driver's } \\
\text { license, lift/carry } \\
\text { heavy objects }\end{array}$ & $\begin{array}{c}\text { Mean }=70,868 \\
\text { Min }=44,261 \\
\text { Max }=89,836 \\
\text { Mode }=50,000 \mathrm{~s}\end{array}$ \\
\hline DNA analyst & 6 & $\begin{array}{l}\text { BS in a physical or } \\
\text { natural science } \\
\text { Some prefer MS }\end{array}$ & $\begin{array}{l}\text { Molecular biology, } \\
\text { biochemistry, } \\
\text { genetics, statistics, } \\
\text { population } \\
\text { genetics/statistics }\end{array}$ & $\begin{array}{l}3-5+\text { years in a } \\
\text { forensic DNA lab } \\
\text { Serology analysis } \\
\text { also preferred }\end{array}$ & $\begin{array}{l}\text { Work well with } \\
\text { others, self- } \\
\text { motivated, detail } \\
\text { oriented }\end{array}$ & $\begin{array}{c}\text { Mean }=57,181 \\
\text { Min }=50,000 \\
\operatorname{Max}=71,934 \\
\text { Mode }=50,000- \\
60,000\end{array}$ \\
\hline $\begin{array}{l}\text { Toxicologist/ } \\
\text { chemist }\end{array}$ & 8 & $\begin{array}{l}\text { Minimum BS in } \\
\text { chemistry } \\
\text { Some prefer MS } \\
\text { or PhD }\end{array}$ & $\begin{array}{l}\text { Heavy emphasis on } \\
\text { chemistry courses }\end{array}$ & $\begin{array}{l}\text { Entry level 6+ } \\
\text { months } \\
\text { Level II or III } \\
\text { needs 2+ years }\end{array}$ & $\begin{array}{l}\text { Team player, open } \\
\text { minded, good } \\
\text { hearing and vision }\end{array}$ & $44,261-56,859$ \\
\hline
\end{tabular}

Table 1 lists jobs for criminalists and crime scene investigators (CSIs); these two job titles were grouped together because of the similarities in duties, though the criminalist position generally requires a higher level of academic proficiency. Table 2 contains evidence specific job titles. For each of the five positions in Table 2, a bachelor's degree in a science such as biology or chemistry is preferred, along with a minimum one year of experience. Table 3 comprises jobs specific to the fields of biology and or chemistry. These jobs differ from those listed in Table 2 in that the analyses performed are directly involving biology or chemistry whereas the evidence specific jobs (Table 2) involve focused training where a foundation in biology or chemistry is essential.

Findings from the results section become essential in implementing a forensic science career advising strategy. The strategy we propose grew out of an exploration of various theoretical approaches utilized in career counseling. Below we provide an overview of some of these theoretical approaches, and following that, we articulate our recommendation for the optimal advising session.

\section{Discussion}

\section{Theoretical approach}

Myriad theories have been purported in the practice of career counseling, such as "decision theory", "existential theory", "constructionist theory", and "systems theory" [8-12]. In an article on applying decision theory to career advising outline eight steps: (1) define the problem, which would be akin to selecting a major or area of study, (2) identify the important aspects, such as asking if the student (advisee) has the skills, background, capacities and endurance, (3) rank the important aspects of the career, (4) eliminate incompatible steps (e.g., disregard jobs not matching preferences), (5) test sensitivity to changes in preferences, meaning recheck the motivation to follow a particular career path while offering alternatives, and reexamine above stages (i.e., steps 1 through 5), (6) collect additional information based on promising alternatives, (7) rank alternatives by overall desirability, and (8) outline steps to actualize the best alternative, meaning to develop a plan based on the preferred option [8]. While this eight step theoretical approach may assist students in deciding if the desired career path is right for them, our challenge is often getting past the first step, where students know they are interested in forensic science, but have no way to make the decision of what to study (i.e., there is a challenge in picking the major or field of study). The reason for this is that they are not familiar enough with the kinds of forensic science jobs available.

Another theoretical approach bases career decision making on existential theory. For example, Cohen provides a four-stage process: (1) responsibility stage: in this stage, advisees become mindful of the freedom of choice and cognizant of the responsibility of their career decision, (2) evaluation stage: advisees assess other career possibilities in addition to their top choice, (3) take action: put into operation career decisions, and (4) reevaluate: determine if decisions provide both personal meaning and opportunities for authentic existence [9]. A strength of the existential theory is that it enables students to get in touch with how they feel about their choices through a process of self-examination and reflection. In forensic science career advising, the "take action" part of the existential theory is where we find the greatest challenge. Our strategy further develops this aspect through creating specific steps; without specificity students tend to get lost in the "CSI effect" and derailed from a realistic path to their goal. 
Unlike decision theory and existential theory, constructionist theory, as described by Obi, does not offer steps or stages in career decision making but emphasizes a rather fluid approach [10]. Obi asserts that people need not be isolated from their environments, meaning people should immerse themselves with like-minded individuals pursuing the same or similar career options. Career counseling is characterized by a reflective process where students focus on creating the self, through writing and revising biographical narratives "taking place in a context of multiple choices from a diversity of options or constraints". The shift moves from focusing on a career choice to "empowering self-affirmation and intentionality" [10].

In forensic science career advising, students often feel an affinity for forensic science overall without knowing which specialization to pursue; they seek guidance on definitive steps and action items, such as what to major in, what courses to take, where to find a job, and so forth. The self-affirmation and intentionality described by Obi develops as students examine forensic science job listings and note how they resonate with the descriptions, qualifications, duties, and so on [10]. In a sense, students are empowered simply by having definitive steps and action items because this helps form a concrete plan, which builds confidence and self-assuredness.

The fourth and final approach to career advising discussed here is a systems theory framework [11-13]. Systems theory has been considered as a meta-theoretical account of career development. Derived from a contextual model of adolescent decision making, the main idea of a systems theory framework in student advising is that time and context should be considered when selecting a career, and that contextual elements should be included in relation to the future in career development theory and practice. Contextual elements include the student's culture, society or environment, family, geographic location, socioeconomic status, and historical factors. Established now for over 20 years, this approach is a well-developed framework and internationally widespread [14].

Of the four theories reviewed, (1) decision, (2) existential, (3) constructionist, and (4) systems, we believe forensic science career advising resonates most with systems theory. The contextual elements mentioned above are what largely determines a student's draw toward forensic science to start. An exploration of these is what determines the final specific forensic science specialization the student will base their educational and experiential background on as they work toward the end goal of landing the targeted job and establishing their career.

\section{A modified system theory approach}

Herein we offer a modified systems theory approach to career development in forensic science. Our approach is humanistic rather than mechanistic albeit there are steps involved. It touches on intuitively gauging advisee interests and skill sets, largely through an interview-type strategy, characterized by dialogue, self-analysis, and a series of "to do" list items. The approach is a process whereby students come to see a career path and curricular plan unfold by identifying target jobs and analyzing elements of those jobs, such as description, duties, qualifications, region (location), education or degree requirements, and so on. This is done first, followed by selecting a major, and minor if applicable, then completing coursework and engaging in any additional experiential activities (e.g., research or internships). Completion of the coursework and additional activities thus prepares the student for the targeted forensic science job, which was the actual starting point. This is a rather recursive process, where we begin with the end-the targeted forensic science job.

\section{A three-step recursive process}

The end goal is the targeted forensic science job. Thus, the first step is to flesh out jobs of interest. Through dialogue leading to self-discovery, the outcome of this first step is that the student becomes aware and realistic about his or her desires and skills, and the variety of forensic science jobs available. This leads the student to be able to focus on one or two areas particularly, or decide to choose another career path altogether. This is the myth-busting stage. The second step is to determine what major or field of

\begin{tabular}{|c|c|c|}
\hline Steps & Action & Outcome \\
\hline 1 & $\begin{array}{l}\text { Advisor opens dialogue with the student advisee } \\
\text { about his or her skillset, preferences, and forensic } \\
\text { science interests by reviewing current job listings: } \\
\text { position description, duties and requirements, } \\
\text { education, etc. }\end{array}$ & $\begin{array}{l}\text { Student becomes knowledgeable about forensic } \\
\text { science entry level jobs and discovers an area of } \\
\text { interest upon which to focus, based on positive } \\
\text { outcomes from studying position descriptions } \\
\text { Or, repeats Step } 1 \text { Action }\end{array}$ \\
\hline 2 & $\begin{array}{c}\text { Student advisee selects a course of study: picks a } \\
\text { major or double major, and or minor(s); continues } \\
\text { dialogue with advisor }\end{array}$ & $\begin{array}{l}\text { Student pursues the degree(s); participates in any } \\
\text { extra experiential learning opportunities (i.e., } \\
\text { research, internships, workshops) } \\
\text { Or, repeats Step } 1 \text { and or } 2 \text { Action }\end{array}$ \\
\hline 3 & Student develops a resume and begins the job hunt & $\begin{array}{c}\text { Student secures desired job } \\
\text { Or, repeats Step } 2 \text { Action, or if need be, repeats } \\
\text { Step } 1 \text { Action and selects a different course of } \\
\text { study either in forensic science or another area }\end{array}$ \\
\hline
\end{tabular}


study is most appropriate. In this second step, the advisee learns to evaluate and design an appropriate curriculum: select a major area of study, a minor or second major if appropriate, and plan any extracurricular research or internship-type experiences as needed or desired. In the third step, which invariably overlaps with the second step through periodic meetings, the advisee visits a career services center and creates and or finalizes a resume. The advisee pinpoints selected job listings and begins submitting applications near to or shortly after graduation, ideally. Table 4 details this three-step process, and lists projected outcomes as well. It is noteworthy that this method of advising is not entirely linear; rather, it may be recursive, with advisees occasionally vacillating between steps before step 3 comes to fruition.

The process here is tailored toward the university undergraduate student seeking a bachelor's degree followed by a job upon graduation, with the possibility of continuing schooling for a master's degree in forensic science, or biology or chemistry. Next is an example of how the process unfolds.

Step 1: Open dialogue with the student advisee about forensic science and his or her academic aptitude. Direct the student to the website of the American Academy of Forensic Sciences (www.aafs.org); click the "Resources" link, followed by the "Employment Opportunities" link. Or, alternatively, direct the student to the website www.Crime-Scene-Investigator.net; click "Employment", then click job-specific links. This brings the student to the list of current job postings in a wide variety of forensic specializations. Show the student examples of the jobs listed and use these resources as a springboard to dialogue with him or her about interests, skills, expectations, and other contextual elements such as flexibility or not regarding geographic location, salary, and the realities of the job. The job postings themselves lead the way in a student's self-discovery that the career advisor can intuit and use to support the student in his or her decision making.

Step 2: The student identifies the jobs he or she is most drawn to and begins to formulate a curriculum. Based on the job description, qualifications, and requirements, the position announcements obviate what courses are needed, such as molecular biology, genetics, statistics, criminal justice, etc. Please refer to Table 1,2 and 3 for examples of the kinds of information gleaned from job descriptions. This information can be used in discussions with the advisee. These discussions and the information provided will typically enable the student to select a major field of study, and or an appropriate minor. If a student is stuck at this stage, he or she is either rethinking a career in forensic science and may switch entirely to a different area, which can be identified through dialogue with the advisor, or he or she may need time to digest all the information and come back for additional advising.

Step 3: The student pursues the apt coursework and is encouraged to visit the campus career resource center to begin developing a resume. Advisors are urged to stay in touch with their advisees and remind students to check job postings periodically to stay on track. When the time is right, the student will have several jobs for which they are prepared to apply.

The above steps follow an apparent linear path; however, it is good to remember that at any point in time and perhaps on several occasions, it is ideal for student advisees to meet with their advisors to recheck the educational and job-goal plan. Slight modifications are not unusual, and reaffirming choices helps streamline the process of moving through school and ultimately transitioning to the workforce.

\section{Conclusion}

Presented here was a review of the types of entry level jobs in forensic science which may be used in career advising. Current job postings assist students in understanding the requirements of available positions and to develop an appropriate educational curriculum to achieve the end goal of securing a specific forensic science job. Identifying the targeted job also drives the best resume development and sustains academic focus. Students interested in forensic science careers requiring postgraduate education, such as a master's degree, doctorate, medical, dental or law degree, have distinctive options; we therefore suggest a slightly different advising approach, which was beyond the scope of this paper, but will be forthcoming in a subsequent study.

\section{References}

1. Stankiewicz H (2007) Investigating the Worldwide Popularity of Forensics. Digital Commons 1-20.

2. CSI fuels forensic science degree rise, The Telegraph, 07 September 2017.

3. Vicary A, Zaikman Y (2017) The CSI Effect: An Investigation into the Relationship between Watching Crime Shows and Forensic Knowledge. N Am J Psychol 19: 51-64.

4. Cole SA, Dioso-Villa R (2009) Investigating the 'CSI Effect' Effect: Media and Litigation Crisis in Criminal Law. Stanford Law Rev 61: 1335-73.

5. Shelton DE (2008) The 'CSI Effect': Does It Really Exist? National Institute Justice J 1-7.

6. American Academy of Forensic Sciences (September-October 2016) Resources, Employment.

7. Crime Scene Investigator Network (September-October 2016) Employment.

8. Gati I, Fassa N, Houminer D (1995) Applying Decision Theory to Career Counseling Practice: The Sequential Elimination Approach. Career Dev Q 43: 211-20.

9. Cohen BN (2003) Applying Existential Theory and Intervention to Career Decision-Making. J Career Dev 29: 195-209.

10. Obi OP (2015) Constructionist career counseling of undergraduate students: An experimental evaluation. J Vocat Behav 88: 215-19.

11. Patton W, McMahon M (2006) The Systems Theory Framework of Career Development and Counseling: Connecting Theory and Practice. Int J Adv Couns 28: $153-66$.

12. McMahon M (2005) Career counseling: applying the systems theory framework of career development. J Employ Couns 42: 29-38. 
13. McMahon M (2011) The systems theory framework of career development. J Employ Couns 48: 170-2.

14. McMahon M, Patton W (2015) The Systems Theory Framework of career development: 20 years of contribution to theory and practice. Aust J Career Dev 24: 141-7.

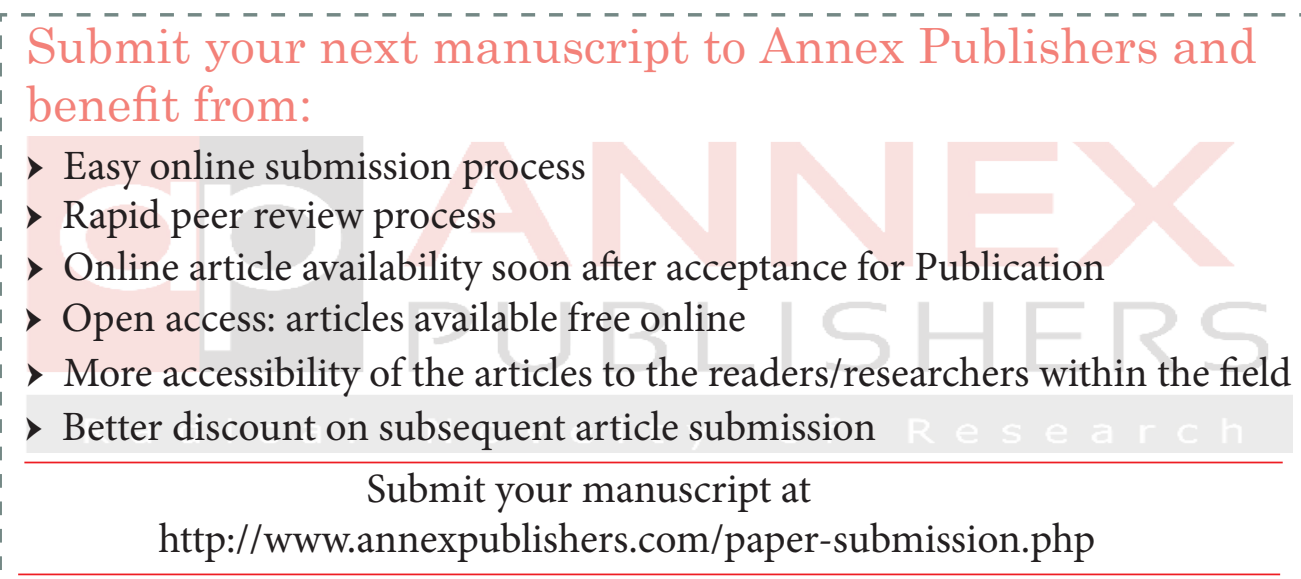

